\title{
POSTHARVEST CONTROL OF Pseudococcus viburni (HEMIPTERA: PSEUDOCOCCIDAE) IN POMEGRANATES (Punica granatum) BY IMMERSION IN WARM DETERGENT SOLUTIONS
}

\author{
Carlos Carpio $^{1}$ and Tomislav Curkovic ${ }^{2 *}$ \\ ${ }^{1}$ College of Natural Resources, Polytechnic School of Chimborazo (ESPOCH), Panamericana Sur Km 1 \\ $1 / 2$, Riobamba, Ecuador. \\ ${ }^{2}$ Dept. Crop Protection, School of Agronomic Sciences, University of Chile, Santa Rosa 11315, Santiago, \\ Chile. \\ *Corresponding author E-mail: tcurkovi@uchile.cl
}

\begin{abstract}
The obscure mealybug Pseudococcus viburni is a major quarantine pest of pomegranates (Punica granatum) in Chile, causing significant rejections during postharvest fruit inspections. To develop alternative control measures, infested pomegranates were immersed in one of the sixteen post-harvest treatments, combining the following four factors in a completely randomized block design with a factorial structure: detergent concentration ( 0 and $1 \%$ ), water temperature $\left(15\right.$ or $\left.47^{\circ} \mathrm{C}\right), \mathrm{pH}(5.5$ and 8.5), and exposure time ( 6 and $15 \mathrm{~min}$ ). After immersions, pomegranates were stored for one month at cold storage $\left(5^{\circ} \mathrm{C}\right.$ ) and followed by $24 \mathrm{~h}$ at room temperature. The number of total live mealybugs (survivorship) at different developmental stages (I, II, and III nymphal instars, and adult females) was counted. Water temperature had a significant effect in reducing total mealybug survival, but there were no significant interactions with remaining factors. Individually, detergent concentration, $\mathrm{pH}$, and exposure time did not have statistically significant effects, but the interaction detergent $\mathrm{x}$ $\mathrm{pH} \times$ exposure time (for all mealybugs) and detergent $\mathrm{x} \mathrm{pH}$ (for II and III instar nymphs) reduced significantly mealybug infestation. While some treatments significantly reduced the population of $P$. viburni, with some treatment combinations reducing infestation up to $98 \%$, there were always some survivors from all stages; therefore, no treatment satisfied international quarantine criteria for postharvest. It is important to note that the treatments did not affect fruit quality, suggesting that further evaluations of these factors at higher levels could be a promising avenue for pest control.
\end{abstract}

Key words: Detergent, exposure time, hot water treatment, mealybug, $\mathrm{pH}$.

\section{INTRODUCTION}

Mealybugs (Hemiptera: Pseudococcidae), mainly Pseudococcus viburni (Signoret), are the most important quarantine pests for exports of Chilean pomegranates (Punica granatum L.) when found in postharvest inspections (Curkovic et al., 2015). Postharvest control against $P$. viburni was traditionally done by fumigation with methyl bromide (Pryke and Pringle, 2008), but this product is subject to strict environmental restrictions (Hegglin et al., 2015). New treatments to control mealybugs are thus needed in the pomegranate industry.

Hot water is a feasible treatment against arthropods (Vincent et al., 2003). Immersions of fruits in hot water have been used as a postharvest control method against several pests, including mealybugs (Haviland et al., 2005). However, no reports of this control method are available for pomegranates. Similarly, detergent or soap solutions have been reported as a postharvest treatment against pests (Vincent et al., 2003; Follett and Neven, 2006), but their efficacy

Received: 24 January 2018. $\quad$ Accepted: 28 March 2018. 
against pomegranates-infesting $P$. viburni is yet unknown. There is no available research about the effect of $\mathrm{pH}$ variation on pest control. Finally, exposure time of fruits to these control treatments is important because longer times can lower fruit quality (Paull and Chen, 2000). Until now, no combination of these treatments has been tested against mealybugs.

The objective of this study was to evaluate the effects of four factors (detergent concentration, water temperature, $\mathrm{pH}$, and exposure time) and their interactions in the reduction of $P$. viburni by immersion of infested pomegranates in combining solutions in order to help develop a postharvest treatment against this pest.

\section{MATERIALS AND METHODS}

Fruit source. Fruits from a pomegranate commercial orchard cv. Wonderful at Huechún (-33.080087, -70.760332), Metropolitan Region, Chile, were used. The orchard was sprayed with insecticides, mainly targeting mealybugs, during the fruiting season. Despite of that, an average of 6.7 live mealybug individuals (adults and nymphs) per fruit were found in a sample of 52 fruits $(92.4 \%$ infested) collected and dissected on May 15, 2013. A number of 256 fruits was collected on the same day and taken to the laboratory to conduct the experiments.

Experimental design. A completely randomized block design with a $2^{4}$ factorial structure was used. The treatments consisted of detergent at 0 or $1 \% \mathrm{v} / \mathrm{v} \times$ two water temperatures $(15 \pm 2$ or $47 \pm$ $\left.2^{\circ} \mathrm{C}\right) \mathrm{x}$ two $\mathrm{pH}(5.5$ or 8.5$) \mathrm{x}$ two exposure times $(6$ or $15 \mathrm{~min}$ ). Treatment date was used as a blocking factor. Each treatment had four replicates, with a total of 16 infested fruits (4/replicate). The tap water used had a $\mathrm{pH}$ of 7.8; phosphoric acid was used to reduce the $\mathrm{pH}$, and sodium hydroxide to increase it to the above-mentioned level. The agricultural detergent used was TS-2035 (Pace International LLC. Ltda., Santiago, Chile), a neutral liquid product containing mainly anionic and non-ionic surfactants (17-23\%) (Curkovic, 2016). Sixteen additional pomegranates were assigned to a control treatment (no immersion) and left in the cold room at $5^{\circ} \mathrm{C}$ of one month.

\section{Mealybug rearing}

Pseudococcus viburni from the orchard were reared over etiolated shoots of potatoes. The potatoes were placed into plastic boxes $(30 \times 17 \times$ $9 \mathrm{~cm}$ ), with arena disinfected with boiling water. The boxes were settled into a breeding cabinet at $25 \pm 2^{\circ} \mathrm{C}, 60 \% \mathrm{RH}$, and 8 hours of photoperiod of light and 16 hours of dark.
Fruit infestation methods. Individuals used for experiments were collected gently from the potatoes with a small brush \# 2. Three third instar nymphs and two adult females (assessed using descriptions by Oyarzún and González, 2005) were placed in the fruit's calyx cavity for $24 \mathrm{~h}$ before experiments, and set in a wire basket. Thus, there was an estimated average of 12 mealybug individuals ( 6.7 from the field infestation +5 added before immersions) per fruit.

Immersion procedure, postharvest treatments, and fruit storage. Baskets with infested fruits were immersed in $15 \mathrm{~L}$ pots containing $10 \mathrm{~L}$ of treatment solutions. Water was heated to the selected temperature on an industrial stove and kept at that level on a thermo ceramic hot plate (McQueen Laboratory Supply Company, Danville, Indiana, USA). After treatments, fruits were taken off the pot and allowed to dry for $10 \mathrm{~min}$. Afterwards, they were packed in regular pomegranate export boxes, stored at $5{ }^{\circ} \mathrm{C}$ and $80 \% \mathrm{RH}$ at the School of Agriculture's Postharvest Research Center, University of Chile, for 30 days, and finally kept at room temperature for $24 \mathrm{~h}$ before evaluation (Curkovic et al., 2015; Curkovic, 2016).

Measurements. After storage, fruit were dissected, and live mealybugs (hydrated, showing no evident wax removal, and able to walk after stimuli with a small brush) on the fruit and in the calyx cavity were counted. The average number of live individuals per treatment, both total mealybugs and by development stage, was counted. Mealybug reduction (\%) was estimated as: 100 * $\left(1-S_{t i} / S_{w t}\right)$, where $S_{t i}$ is the number of survivors in treatment " $\mathrm{i}$ " and $S_{\mathrm{wt}}$ are the survivors found in the worst treatment (i.e., the one with the largest number of live mealybugs after immersion and cold storage). Fruits were weighed on a scale before $(\mathrm{Wb})$ immersion and after $(\mathrm{Wa})$ the cold treatment following the methodology given by Gould and McGuire (2000), followed by $24 \mathrm{~h}$ at room temperature. Weight losses were determined using the following formula: $100 *[1-$ Wa / Wb]. Possible damage on aril and epidermis was evaluated using a 12 point visual scale (Horsfall and Garrett, 1945). Skin color was measured with a tri-stimuli CR-300 colorimeter (Minolta, Tokyo, Japan), with a D65 light source, with a $0^{\circ}$ viewing angle, calibrated to a white porcelain reference plate, and utilizing the $\mathrm{L} \times \mathrm{C} \times \mathrm{h}^{\circ}$ system (lightness, chrome and tone angle, respectively). The $L$ value obtained shows the color lightness $(0=$ black, $100=$ white). Three measurements were made on the opposite sides of each fruit. 
Statistical analyses. Treatments were evaluated using a General Linear Mixed Model (GLMM) with different residual variance for the two temperatures, leaving the factors and the interactions fixed. The effects were tested on the survivor count of the total (all instars together) and each mobile mealybug life stage. Additionally, all treatments were compared with the control using an ANOVA where the total survivor count was used as the response variable. To improve normality, total mealybug survivor counts were transformed by mean of square root. Percentage of fruit weight loss, parameters of epidermis, and aril color were analyzed using the GLMM. The LSD Fisher test was used to detect significant differences between treatment means with a $95 \%$ level of significance. Percentage of fruit weight loss was transformed by mean of Bliss transformation. Analyses were performed using the statistical software Infostat version 2012, which is linked to R statistical software (Di-Rienzo et al., 2012).

\section{RESULTS}

Survivorship. Total survival of $P$. viburni to postharvest treatments varied with treatment. Temperature was the only factor reducing total survival $(F=9.87 ; \mathrm{df}=1 ; P=0.0029$, Table 1$)$. Thus, $14.97( \pm 2.25)$ mealybugs, on average, were found on the fruit at a temperature of $47^{\circ} \mathrm{C}$, when compared to $34.41( \pm 5.57)$ mealybugs found at $15^{\circ} \mathrm{C}$, regardless the effects of other factors. Looking at the interactions, there was also a significant reduction in survivorship when combining detergent concentration $\mathrm{x} \mathrm{pH} \times$ exposure time $(F=4.95$; $\mathrm{df}=1 ; P=0.0307)$. The treatment with $1 \%$ detergent solution at $\mathrm{pH} 8.5$ immersed during $15 \mathrm{~min}$ resulted in the lowest mealybug survival, whereas that with $0 \%$ detergent solution at $\mathrm{pH} 5.5$ for 6 min of immersion resulted in the highest survivorship (Table 2). However, no treatment eliminated the mealybug population. Considering the detergent $\mathrm{x} \mathrm{pH} \times$ exposure time interaction, the detergent reduced mealybug survival after the 15 min immersions at $\mathrm{pH} 8.5$ and 5.5, and after the 6 min immersions at pH 5.5. Immersions for $6 \mathrm{~min}$ without detergent at pH 5.5 and for 15 min with detergent at $\mathrm{pH} 8.5$ yielded greater survival. Immersions for $6 \mathrm{~min}$ without detergent at $\mathrm{pH} 5.5$ were statistically different from immersions for 15 min with detergent at $\mathrm{pH}$ 8.5. The estimated total $P$. viburni reduction for the best treatment (with $1 \%$ detergent, 15 min exposure, $\mathrm{pH} 8.5$, and the highest water temperature) was $90.2 \%$.

When considering only the survival of II and III instar nymphs, the maximum mealybug reduction was even greater $(98.2 \%)$, and the solution temperature $(F=10.45 ; \mathrm{df}=1 ; P=0.0021$, Table 1) was again a significant individual factor for mealybug control. The interaction detergent $x$ $\mathrm{pH}$ also achieved significant mortality of nymphs II and III ( $\mathrm{F}=8.92 ; \mathrm{df}=1 ; P=0.0051$, Table 1$)$. Significantly lower numbers of II and III instar nymphs were found when the detergent was used at $\mathrm{pH} 5.5$ for the detergent $\mathrm{x} \mathrm{pH}$ interaction, in comparison with the other combinations of factors. Moreover, when no detergent was used, there were more surviving II and III instar nymphs at pH 5.5 (Table 3). However, as with the total survival population, none of the treatments completely eliminated any single life stage. Statistical differences were found among the treatments in the ANOVA with a control $(\mathrm{F}$ = 2.16; $\mathrm{df}=16 ; \mathrm{P}=0.0206)$; treatments with the worst effects (treatments with lower temperature and exposure time) shown in the results of the factorial structure design are statistically similar to the control.

Fruit quality. Fruit quality parameters presented no significant effects after immersions: weight loss, internal fruit damage, external fruit damage, and color ( $\mathrm{df}=1, \mathrm{P}>0.05$ in the four parameters).

\section{DISCUSSION}

No treatment resulted in complete fruit disinfestation, a requirement for postharvest control of a regulated quarantine pest such as $P$. viburni. However, there was a significant reduction on $P$. viburni survival in some post-harvest treatments. The temperature had an effect with the total survival of $P$. viburni and with the II and II instar nymphs, while the interactions of detergent concentration $\mathrm{x} \mathrm{pH} \times$ exposure time had an effect on the total survival of P. viburni, and the detergent concentration $\mathrm{x} \mathrm{pH}$ had an effect on the II and II instar nymphs. Thus, new tests should be conducted, increasing the levels of these promissory factors to hopefully achieve $100 \%$ mealybug control. Regarding water temperature, it probably reached a lower value inside the pomegranate calyx cavity compared to the temperature of the detergent solution, resulting in a lower control of mealybugs. In fact, pomegranates did not show any sign of either external or internal damage after the treatments. However, it has been described that pomegranates subject to heat treatment (as immersions) before cold storage induced tolerance to low temperatures, improved the functional and nutritional properties of the fruit (Mirdehghan et al., 2006; 2007). Some papers show immersion in hot water (no detergent added) as a feasible postharvest alternative against mealybugs, but at higher temperature for longer 
Table 1. Factorial ANOVA on Pseudococcus viburni survivors (all stages and II and III instar nymphs) after postharvest treatments (water temperature 15 or $47 \pm 2^{\circ} \mathrm{C} ; 0$ or $1 \% \mathrm{v} / \mathrm{v}$ detergent concentration; pH 5.5 or 8.5; and 6 or 15 min exposure time, plus one month storage at $5^{\circ} \mathrm{C}$ followed by $24 \mathrm{~h}$ at room temperature. No significant effects were found for first instar nymphs.

\begin{tabular}{|c|c|c|c|c|}
\hline \multirow[t]{2}{*}{ Factors and interactions } & \multicolumn{2}{|c|}{ All stage survivors } & \multicolumn{2}{|c|}{$\begin{array}{l}\text { II and III instar } \\
\text { nymphs survivors }\end{array}$} \\
\hline & F value & $p$ value & F value & $p$ value \\
\hline Detergent & 1.35 & 0.2511 & 5.5 & 0.0228 \\
\hline Temperature & 9.87 & $0.0029^{*}$ & 10.45 & $0.0021^{*}$ \\
\hline $\mathrm{pH}$ & 0.33 & 0.5675 & 0.33 & 0.5688 \\
\hline Exposure time & 2.45 & 0.1239 & 2.13 & 0.1503 \\
\hline Deterg. $x$ temp. & 0.03 & 0.8723 & 0.33 & 0.5688 \\
\hline Deterg. $\times \mathrm{pH}$ & 0.05 & 0.8251 & 8.52 & $0.0051^{*}$ \\
\hline Deterg. $\mathrm{x}$ time & 0.0037 & 0.9519 & 0.46 & 0.5009 \\
\hline Temp. x pH & 0.34 & 0.5607 & 0.02 & 0.8763 \\
\hline Temp. $x$ time & 3.23 & 0.0784 & 0.53 & 0.4687 \\
\hline $\mathrm{pH} \times$ time & 0.05 & 0.8251 & 0.46 & 0.5009 \\
\hline Deterg. $\mathrm{x}$ temp. $\mathrm{xpH}$ & 0.005 & 0.9439 & & \\
\hline Temp. $x \mathrm{pH} \times$ time & 0.07 & 0.7862 & & \\
\hline Deterg. $x$ temp. $x$ time & 0.49 & 0.4892 & & \\
\hline Deterg. $\mathrm{x} \mathrm{pH} \times$ time & 4.95 & $0.0307^{*}$ & & \\
\hline
\end{tabular}

*: significant $\mathrm{p} \leq 0.05$.

Table 2. Effects of the temperature, detergent concentration, $\mathrm{pH}$ and exposure time on mean Pseudococcus viburni mobile stages (total stages) count, after postharvest immersion treatments, plus one month cold storage at $5^{\circ} \mathrm{C}$ plus by $24 \mathrm{~h}$ at room temperature.

\begin{tabular}{|c|c|c|c|c|c|c|c|c|c|}
\hline \multirow[b]{2}{*}{$\begin{array}{l}\text { Temp. } \\
\left({ }^{\circ} \mathrm{C}\right)\end{array}$} & \multirow[b]{2}{*}{$\begin{array}{l}\text { Deterg. } \\
\text { conc. } \\
(\% \mathrm{v} / \mathrm{v})\end{array}$} & \multirow[b]{2}{*}{$\mathrm{pH}$} & \multirow[b]{2}{*}{$\begin{array}{l}\text { Exp. } \\
\text { time } \\
\text { (min) }\end{array}$} & \multirow[b]{2}{*}{ Total stages } & Effect & \multirow[b]{2}{*}{ Total stages } & \multicolumn{3}{|c|}{ Effect } \\
\hline & & & & & $\mathrm{T}^{\mathrm{o}} \mathrm{C}$ & & & $\begin{array}{l}\text { t. co } \\
\text { exp }\end{array}$ & \\
\hline $15 \pm 2$ & 0 & 5.5 & 6 & $34.41 \pm 5.57$ & $\mathrm{~b}$ & $30.65 \pm 12.84$ & a & & \\
\hline $15 \pm 2$ & 0 & 8.5 & 6 & $34.41 \pm 5.57$ & $\mathrm{~b}$ & $25.29 \pm 10.85$ & a & $\mathrm{b}$ & c \\
\hline $15 \pm 2$ & 0 & 5.5 & 15 & $34.41 \pm 5.57$ & $\mathrm{~b}$ & $19.13 \pm 4.54$ & a & $\mathrm{b}$ & c \\
\hline $15 \pm 2$ & 0 & 8.5 & 15 & $34.41 \pm 5.57$ & $\mathrm{~b}$ & $28.13 \pm 7.07$ & a & $\mathrm{b}$ & \\
\hline $15 \pm 2$ & 1 & 8.5 & 6 & $34.41 \pm 5.57$ & b & $30.63 \pm 10.96$ & a & $\mathrm{b}$ & \\
\hline $15 \pm 2$ & 1 & 5.5 & 15 & $34.41 \pm 5.57$ & $\mathrm{~b}$ & $16.50 \pm 10.18$ & & $\mathrm{~b}$ & c \\
\hline $15 \pm 2$ & 1 & 8.5 & 15 & $34.41 \pm 5.57$ & $\mathrm{~b}$ & $15.63 \pm 6.69$ & & & c \\
\hline $15 \pm 2$ & 1 & 5.5 & 6 & $34.41 \pm 5.57$ & $\mathrm{~b}$ & $21.63 \pm 25.80$ & a & $\mathrm{b}$ & c \\
\hline $47 \pm 2$ & 0 & 5.5 & 6 & $14.97 \pm 2.25$ & $\mathrm{a}$ & $30.65 \pm 12.84$ & a & & \\
\hline $47 \pm 2$ & 0 & 8.5 & 6 & $14.97 \pm 2.25$ & $\mathrm{a}$ & $25.29 \pm 10.85$ & a & $\mathrm{b}$ & c \\
\hline $47 \pm 2$ & 0 & 5.5 & 15 & $14.97 \pm 2.25$ & a & $19.13 \pm 4.54$ & a & $\mathrm{b}$ & c \\
\hline $47 \pm 2$ & 0 & 8.5 & 15 & $14.97 \pm 2.25$ & a & $28.13 \pm 7.07$ & a & $\mathrm{b}$ & \\
\hline $47 \pm 2$ & 1 & 8.5 & 6 & $14.97 \pm 2.25$ & a & $30.63 \pm 10.96$ & a & $\mathrm{b}$ & \\
\hline $47 \pm 2$ & 1 & 5.5 & 15 & $14.97 \pm 2.25$ & $\mathrm{a}$ & $16.50 \pm 10.18$ & & $\mathrm{~b}$ & c \\
\hline $47 \pm 2$ & 1 & 8.5 & 15 & $14.97 \pm 2.25$ & a & $15.63 \pm 6.69$ & & & c \\
\hline $47 \pm 2$ & 1 & 5.5 & 6 & $14.97 \pm 2.25$ & a & $21.63 \pm 25.80$ & a & $\mathrm{b}$ & c \\
\hline
\end{tabular}

Means and SE with the same letter within a column are not significantly different $(\mathrm{P} \leq 0.05)$, ANOVA and LSD Fisher test. 
Table 3. Effects of the temperature, detergent concentration, $\mathrm{pH}$ and exposure time on mean Pseudococcus viburni mobile stages (II and III instar nymphs) count, after postharvest immersion treatments, plus one month cold storage at $5^{\circ} \mathrm{C}$ plus by $24 \mathrm{~h}$ at room temperature.

\begin{tabular}{|c|c|c|c|c|c|c|c|}
\hline \multirow[t]{2}{*}{ Temp. } & \multirow[b]{2}{*}{$\begin{array}{l}\text { Deterg. } \\
\text { conc. } \\
(\% \mathrm{v} / \mathrm{v})\end{array}$} & \multirow[b]{2}{*}{$\mathrm{pH}$} & \multirow[b]{2}{*}{$\begin{array}{l}\text { Exp. time } \\
\text { (min) }\end{array}$} & \multirow[b]{2}{*}{$\begin{array}{l}\text { II and III } \\
\text { instar } \\
\text { nymphs }\end{array}$} & Effect & \multirow[b]{2}{*}{$\begin{array}{l}\text { II and III } \\
\text { instar } \\
\text { nymphs }\end{array}$} & Effect \\
\hline & & & & & $\mathrm{T}^{\circ} \mathrm{C}$ & & $\begin{array}{c}\text { Deterg. } \\
\text { conc. X pH }\end{array}$ \\
\hline $15 \pm 2$ & 0 & 5.5 & 6 & $7.75 \pm 1.06$ & $\mathrm{~b}$ & $9.30 \pm 1.95$ & b \\
\hline $15 \pm 2$ & 0 & 8.5 & 6 & $7.75 \pm 1.06$ & b & $5.13 \pm 0.66$ & a \\
\hline $15 \pm 2$ & 0 & 5.5 & 15 & $7.75 \pm 1.06$ & b & $9.30 \pm 1.95$ & b \\
\hline $15 \pm 2$ & 0 & 8.5 & 15 & $7.75 \pm 1.06$ & $\mathrm{~b}$ & $5.13 \pm 0.66$ & $\mathrm{a}$ \\
\hline $15 \pm 2$ & 1 & 8.5 & 6 & $7.75 \pm 1.06$ & $\mathrm{~b}$ & $5.81 \pm 1.19$ & a \\
\hline $15 \pm 2$ & 1 & 5.5 & 15 & $7.75 \pm 1.06$ & $\mathrm{~b}$ & $3.00 \pm 0.89$ & a \\
\hline $15 \pm 2$ & 1 & 8.5 & 15 & $7.75 \pm 1.06$ & b & $5.81 \pm 1.19$ & a \\
\hline $15 \pm 2$ & 1 & 5.5 & 6 & $7.75 \pm 1.06$ & $\mathrm{~b}$ & $3.00 \pm 0.89$ & a \\
\hline $47 \pm 2$ & 0 & 5.5 & 6 & $3.88 \pm 4.1$ & a & $9.30 \pm 1.95$ & $\mathrm{~b}$ \\
\hline $47 \pm 2$ & 0 & 8.5 & 6 & $3.88 \pm 4.1$ & a & $5.13 \pm 0.66$ & a \\
\hline $47 \pm 2$ & 0 & 5.5 & 15 & $3.88 \pm 4.1$ & a & $9.30 \pm 1.95$ & $\mathrm{~b}$ \\
\hline $47 \pm 2$ & 0 & 8.5 & 15 & $3.88 \pm 4.1$ & a & $5.13 \pm 0.66$ & a \\
\hline $47 \pm 2$ & 1 & 8.5 & 6 & $3.88 \pm 4.1$ & a & $5.81 \pm 1.19$ & a \\
\hline $47 \pm 2$ & 1 & 5.5 & 15 & $3.88 \pm 4.1$ & a & $3.00 \pm 0.89$ & a \\
\hline $47 \pm 2$ & 1 & 8.5 & 15 & $3.88 \pm 4.1$ & a & $5.81 \pm 1.19$ & a \\
\hline $47 \pm 2$ & 1 & 5.5 & 6 & $3.88 \pm 4.1$ & a & $3.00 \pm 0.89$ & a \\
\hline
\end{tabular}

Means and SE with the same letter within a column are not significantly different $(\mathrm{P} \leq 0.05)$, ANOVA and LSD Fisher test.

periods (Gould and McGuire, 2000). More recently, Redpath et al. (2015) found $60-70 \%$ P. viburni mortality after immersion of apples in hot water $\left(51-52^{\circ} \mathrm{C}\right)$ for $2-3 \mathrm{~min}$. However, values lower than those were obtained here. Thus, higher temperatures should be tested in the future. Because $\mathrm{pH}$ was found in the two significant interactions, it provides support for $\mathrm{pH}$ to be tested at different levels in the future. In fact, Santibáñez (2010) found a significant effect of $\mathrm{pH}$ on detergent insecticidal activity against mealybugs. The detergent used at $1 \% \mathrm{v} / \mathrm{v}$ kept the solution neutral, but it might affect the $\mathrm{pH}$ solution when detergent is used at greater concentrations (Villar 2015).

Previous experience on mobile stages of mealybugs exposed to detergent treatments indicates that the stage in which they are more easily controlled by detergent solutions corresponds to first instar nymph (Curkovic et al., 2007). However, first instar nymphs were by far the most frequent stage in which they were found alive in the present study (Table 2); individuals were mainly found walking on the fruit surface or inside the calyx cavity after treatments and cold storage. These findings suggest that the treatments used could have truly controlled first instar nymphs; however, crawlers might have hatched from egg masses either laid previously in the field or laid by females coming from the field (surviving to immersions) or those used for fruit infestation. Accordingly, eggs of Maconellicoccus hirsutus (Green) (Hemiptera: Pseudococcidae) (Hara and Jacobsen, 2005) were the most resistant stage to hot water $\left(49^{\circ} \mathrm{C}\right.$ for $\left.20 \mathrm{~min}\right)$ treatments attempting to control mealybugs during postharvest. Besides, mealybug adult females have also shown to be more resistant to detergent treatments (Bahder et al., 2013). Future studies should consider the developmental time of instars, and increasing levels of the factors tested herein (combined). This manuscript adds to the growing literature on alternative post-harvest pest control methods. This is timely given the eventual banning of methyl bromide as a postharvest treatment (Bulathsinghala and Shaw, 2014). Based on previous reports, the survival obtained can be reduced by extending the hot temperature treatments (Follet, 2004) with detergent solutions. Thus, successful postharvest hot treatment by immersion should be an environmentally more friendly, simple and safe procedure, and an efficient solution against mealybugs infesting pomegranates. 


\section{CONCLUSIONS}

Pomegranate immersion in warm solutions $\left(47 \pm 2^{\circ} \mathrm{C}\right)$ with detergent at $1 \%, \mathrm{pH}$ at 5.5 or 8.5 , and exposure time of 6 or 15 min significantly reduced $P$. viburni survivorship, but did not reach a quarantine security level, i.e. was not able to eliminate the total population in the calyx cavity of pomegranates. Among all the factors, only water temperature had an individually significant effect on reducing total survivorship, whereas the detergent concentration was significant in nymphs II and III. No interactions between water temperature and the other factors were found. Only the interactions detergent $\mathrm{x} \mathrm{pH}$ $x$ time (in total individuals, all stages together) and the detergent $\mathrm{x} \mathrm{pH}$ (in nymphs II and III) significantly reduced mealybug survivorship. Since neither the individual factors (detergent, temperature, $\mathrm{pH}$ and time) nor their possible combinations significantly affected fruit quality parameters, follow-up tests using greater levels of combinations of these factors to reach total pomegranate mealybug disinfestation are strongly suggested.

\section{ACKNOWLEDGEMENTS}

To Corporación de Fomento de la Producción (CORFO), Santiago, Chile, for funding the Project 11 BPC-10035

\section{LITERATURE CITED}

Bahder, B.W., R.A. Naidu, K.M. Daane, J.G. Millar, and D.B. Walsh. 2013. Pheromone-based monitoring of Pseudococcus maritimus (Hemiptera: Pseudococcidae) populations in concord grape vineyards. J. Econ. Entomol. 106:482-490.

Bulathsinghala, A.T., and I.C. Shaw. 2014. The toxic chemistry of methyl bromide. Hum. Exp. Toxicol. 33:81-91.

Curkovic, T. 2016. Detergents and soaps as tools for IPM in agriculture p. 155-189. In Kaur Gill, H. \& Goyal, G. (eds.). Integrated Pest Management (IPM): Environmentally Sound Pest Management. Intech, Rijeka, Croatia.

Curkovic, T., C. Ballesteros, and C. Carpio. 2015. Integrated management of pomegranate pest (in Spanish) p. 159-232. In Henríquez, J.L., and Franck, N. (eds.). Bases for the cultivation of pomegranate in Chile. University of Chile, Santiago, Chile.
Curkovic, T., G. Burett, and J. E. Araya. 2007. Evaluation of insecticide activity of two agricultural detergents against the long-tailed mealybug, Pseudococcus longispinus (Hemiptera: Pseudococcidae), in the laboratory. Agric. Téc. (Chile). 67: 422-430.

Di-Rienzo, J.A., F. Casanoves, M.G. Balzarini, L. Gonzalez, M. Tablada, and C. W. Robledo2012. InfoStat versión 2012. Grupo InfoStat, FCA, Universidad Nacional de Córdoba, Argentina. URL http://www.infostat.com.ar

Follett, P.A. 2004. Generic vapor heat treatments to control Maconellicoccus hirsutus (Homoptera: Pseudococcidae). J. Econ. Entomol. 97:1263-1268.

Follett, P., and L. Neven. 2006. Current trends in quarantine entomology. Annu. Rev. Entomol. 51:359-385.

Gould, W.P., and R. G. McGuire. 2000. Hot water treatment and insecticidal coatings for disinfesting limes of mealybugs (Homoptera: Pseudococcidae). J. Econ. Entomol. 93:10171020.

Hara, A.H., and C.M. Jacobsen. 2005. Hot water immersion for surface disinfestation of Maconellicoccus hirsutus (Homoptera: Pseudococcidae). J. Econ. Entomol. 98:284-8.

Haviland, D.R., W. J. Bentley, and K.M. Daane. 2005. Hot-water treatments for control of Planococcus ficus (Homoptera: Pseudococcidae) on dormant grape cuttings. J. Econ. Entomol. 98:1109-1115.

Hegglin, M.I., D.W. Fahey, M. Mcfarland, S.A. Montzka, and E.R. Nash. 2014. Twenty questions and answers about the ozone layer: 2014 update. World Meteorological Organization, UNEP, NOAA, NASA and European Comission, Geneva, Switzerland.

Horsfall, J.G.. 1945. An improved grading system for measuring plant diseases. Phytopathology 35:655.

Mirdehghan, S.H., M. Rahemi, D. Martínez-Romero, F. Guillén, J.M. Valverde, P.J. Zapata, et al. 2007. Reduction of pomegranate chilling injury during storage after heat treatment: role of polyamines. Postharvest Biol. Technol. 44:19-25.

Mirdehghan, S.H., M. Rahemi, M. Serrano, F. Guillén, D. Martínez-Romero, and D. Valero. 2006. Prestorage heat treatment to maintain nutritive and functional properties during postharvest cold storage of pomegranate. J. Agric. Food Chem. 54:8495-8500.

Oyarzún, M., and R. González. 2005. Taxonomía, desarrollo y observaciones biológicas del chanchito blanco de los frutales, Pseudococcus viburni (Signoret).(Hemiptera: Pseudococcidae). Rev. Frutícola 26:5-12. 
Paull, R.E., and N.J. Chen. 2000. Heat treatment and fruit ripening. Postharvest Biology and Technology 21:21-37.

Pryke, J.S., and K.L. Pringle. 2008. Postharvest disinfection treatments for deciduous and citrus fruits of the Western Cape, South Africa: a database analysis. S. Afr. J. Sci. 104:8589.

Redpath, S.P., L.E. Jamieson, M.K. D. Hall, S.R. Olsson, M.J. Griffin, A. Chhagan, et al. 2015. Investigating the feasibility of short-duration hot water treatments for apple disinfestation. New Zeal. Plant Prot. 347:340-347.

Santibáñez, D. P. 2010. Evaluation of dehydration and epicuticle wax removal as factors associated to mortality on females of Pseudococcus viburni Signoret (Hemiptera: Pseudococcidae) treated with agricultural detergents [in Spanish]. 51 p. Master of Science tesis. Universidad de Chile, Facultad de Agronomía, Santiago, Chile.
Villar, J. 2015. Effect of the TS-2035 agricultural detergent used as adjuvant for two entomopathogenic fungi and one conventional insecticide sprayed on adult females of the obscure mealybug (Pseudococcus viburni Signoret) (Hemiptera: Pseudococcidae) in the laboratory. [in Spanish]. 77 p. Master of Science thesis. Universidad de Chile, Facultad de Agronomía, Santiago, Chile.

Vincent, C., G. Hallman, B. Panneton, and F. Fleurat-Lessard. 2003. Management of agricultural insects with physical control methods. Annu. Rev. Entomol. 48:261-81. 